\title{
Kinetics Oxidation and Characterization of Cyclically Oxidized Layers at High Temperatures for FeMnSiCrNiCe and FeSiCrNi Alloys
}

\author{
Vinícius Fernandes de Souza *, Alef José Araújo ${ }^{a}$, Josué Lucas do Nascimento Santos \\ Carlos Alberto Della Rovere ${ }^{b}$, Artur Mariano de Sousa Malafaia ${ }^{a}$ \\ ${ }^{a}$ Universidade Federal de São João Del Rei, Praça Frei Orlando, 170, 36307-352, \\ São João Del Rei, MG, Brazil \\ ${ }^{b}$ Universidade Federal de São Carlos, Rodovia Washington Luis, km 235, 13565-905, \\ São Carlos, SP, Brazil
}

Received: January 17, 2017; Revised: July 07, 2017; Accepted: August 08, 2017

\begin{abstract}
Conventional stainless steels are used in cyclic oxidation, but the high amount of $\mathrm{Cr}$ and mainly $\mathrm{Ni}$ increase the price of these alloys. The objective of the present study was to assess the cyclic oxidation resistance of $\mathrm{FeSiCrNi}$ and $\mathrm{FeMnSiCrNiCe}$ alloys in comparison to AISI 304 and AISI 310 stainless steels by evaluating the oxidation kinetics and using characterization techniques to determine the oxides formed. The alloys were melted in induction furnaces and cast in sand molds. Cyclic oxidation tests were carried out in an automated oven in cycles of one hour for heating and maintenance at high temperature $\left(850,950\right.$ or $\left.1050^{\circ} \mathrm{C}\right)$ and 10 minutes for cooling. To characterize the oxidized layers, X-Ray Diffraction (XRD), Scanning Electron Microscopy (SEM) and Energy Dispersive X-Ray Spectroscopy (EDS) analysis were performed. The oxidation kinetics were determined. The results showed that the studied alloys presented better results than AISI 304 at $850^{\circ} \mathrm{C}$, but at $1050{ }^{\circ} \mathrm{C}$, AISI 310 presented the best results. At $950{ }^{\circ} \mathrm{C}$, the $\mathrm{FeSiCrNi}$ alloy presented layer detachment and $\mathrm{FeMnSiCrNiCe}$ presented a higher rate of mass variation than AISI 310, both without oxide detachment. For both alloys, formation of chromium and manganese oxides with parabolic rate of mass gain occurred.
\end{abstract}

Keywords: Cyclic oxidation, FeSiCrNi alloy, FeMnSiCrNiCe, Oxidation kinetics, Layer characterization.

\section{Introduction}

Due to the extensive use of metals at high temperatures in the most diverse environments (petrochemical, steels and cement manufacturing industries), one of the main aspects that must be observed and studied is the metal's oxidation processes to predict application's lifespan. The oxidation process consists of the alloy's reaction in gaseous atmospheres where an oxide layer is formed on the surface of the base metal ${ }^{1}$. The study of oxidation is carried out through oxidation tests in which there is a simulation of the most diverse corrosive environments and a subsequent evaluation of the mass variation per unit area in a given time interval is performed ${ }^{2}$.

The characterization of the oxidized layers after cyclic oxidation tests is critical in understanding the behavior of the alloy and evaluating its oxidation resistance. An important parameter that is analyzed during these types of tests is the coefficient of the oxidation kinetics. This value can be expressed in a graph that relates mass gains per unit area and the number of cycles tested in each temperature. When there is no mass loss as a result of the cyclic oxidation test, it is easier to calculate the oxidation kinetics because the curve is similar to that of an isothermal test. However, when there is continuous spallation this calculation is more complex ${ }^{2}$. With the advancement of the industry and manufacturing processes, the use of metals at elevated temperatures has become more common. Thus, the development of materials that provide better results at higher temperatures were necessary due to the aggressive environment responsible for accelerating the process of alloy oxidation. For this reason, it was necessary to add alloying elements to iron alloys which allow a more controlled oxidation process through the formation of a protective layer on the surface of the base metal ${ }^{3}$.

The use of certain elements may improve the properties of the alloys in regard to oxidation. Chromium is a prime example. It makes the alloy extremely resistant to corrosive environments and is used in the production of protective layers in electro deposition on metallic parts. It is also used, in the majority of times, in the manufacturing of stainless steels producing a steel that is rather superior to common steel in 
regard to the resistance of oxidation at high temperature and corrosion in general ${ }^{1}$. Silicon is another example and is added to stainless steel alloys with the intention of aiding in the formation of the chromium oxide layer in $\mathrm{FeCrSi}$ alloys or as a silica former in $\mathrm{Fe}-\mathrm{Si}$ alloys ${ }^{4}$.

Nickel, even though it does not have the property of formation of an oxidized layer on the metal, also improves the properties of the alloys. It promotes the stabilization of the austenite in stainless steels, which results in a considerable increase in the mechanical properties of the alloy. A down-side, is that it accumulates in the metal/oxide interface in the poor region of the oxidize elements ${ }^{3}$. Manganese should be mentioned because of its affinity with oxygen, although, it is harmful to the oxidation properties due to the fact that manganese oxides gain more mass than other oxides. It is widely used because of its ability to stabilize austenite as well as costing less than nickel ${ }^{5}$.

FeMnSiCrNi alloys are known by their shape memory effect ${ }^{6}$. However, some studies were dedicated to evaluating the corrosion resistance of these alloys ${ }^{5,7}$. The presence of $\mathrm{Cr}$ and $\mathrm{Si}$ helps the formation of passive films in oxidizing environments ${ }^{8}$. Regarding oxidation at high temperatures, studies are still incipient, but Ma et al. ${ }^{9}$ verified the quasi-isothermal oxidation resistance at $800^{\circ} \mathrm{C}$ and de Sousa Malafaia and de Oliveira ${ }^{10}$ demonstrated anomalous behavior, where, after considerable spallation, the alloy returned to present mass gain, with a rate smaller than the initial one.

Although $\mathrm{FeCr}$ alloys can have improved oxidation resistance using small amounts of silicon ${ }^{4}$ and FeSi alloys can also present better behavior at high temperatures with chromium alloying ${ }^{11}$, studies with higher amounts added of both elements are not known by the authors. While Fe-high chromium alloys have at least $11.5 \%$ of $\mathrm{Cr}$ for good corrosion resistance, in Fe-high silicon alloys, the best compositions were noticed around $15 \%$ of silicon ${ }^{12}$. However, one of the reasons to avoid the high use of silicon in iron based alloys is related to the embrittlement generated ${ }^{13,14}$.

Rare earths, like cerium and yttrium, are also used to improve oxidation resistance in Fe-based alloys ${ }^{15-18}$. Rhys-Jones and Grabke ${ }^{16}$ studied the oxidation of $\mathrm{Fe}-\mathrm{Cr}$ alloys using either 0.0001 to $1 \%$ of $\mathrm{Ce}$ or $\mathrm{CeO}_{2}$ and 10 to $20 \%$ of $\mathrm{Cr}$. They observed that the increase of Ce reduced the formation time of the protective layer at the surface by decreasing the growth rates of the chromium oxides formed. Li et al. ${ }^{17}$, studying high temperature oxidation of a $17 \mathrm{Cr}$ ferritic stainless steel (low Mn-content) observed increase of chromium and decrease of manganese content in oxide layer in cerium-bearing steels. The use of different rare earth oxides in a AISI 304L austenitic stainless steel sintered also improved the oxidation resistance ${ }^{18}$.

Therefore, the objective of the present research was to study oxidation resistance at high temperatures of FeSiCrNi and $\mathrm{FeMnSiCrNiCe}$ low-cost alloys (low $\mathrm{Cr}$ and $\mathrm{Ni}$ content), comparing them with conventional austenitic stainless steels and to evaluate mass variation through cyclic oxidation tests. Additionally, characterize the oxidized layers to identify which oxides were formed. Understanding the role of alloying elements in the cyclic oxidation behavior was also an objective of the present paper.

\section{Materials and Methods}

\subsection{Alloys}

The FeSiCrNi ferritic alloy was cast in the oxidation laboratory at the Federal University of São João Del Rei. For this process, a $5 \mathrm{~kW}$ induction furnace was used with a graphite crucible. AISI 1010 steel was used as the iron source and $\mathrm{Cr}, \mathrm{Ni}$ and $\mathrm{Si}$ element sources were more than $99.3 \%$ pure. The cast alloy was subjected to a heat treatment at $800{ }^{\circ} \mathrm{C}$ for a period of 3 hours to ensure microstructural homogeneity.

The FeMnSiCrNiCe austenitic alloy was melted in the casting laboratory of the Materials Engineering Department at the Federal University of São Carlos (DEMa/UFSCar) in an induction furnace using an alumina crucible; the casting was performed by gravity in a sand mold with resin. AISI 1010 low-carbon steel, AISI 304 type austenitic stainless steel and pure elements such as $\mathrm{Mn}, \mathrm{Si}$ and Ce were used for the alloy fusion. During the melting, a thermal blanket protected the metal from oxidation and the melting surface was exposed to an argon atmosphere in order to prevent contamination.

The compositions of the alloys used in this work were determined by EDS analysis, presented in Table 1. The FeMnSiCrNiCe alloy was proposed based on cerium's benefits in oxidation resistance for iron alloys ${ }^{15,16}$. The FeSiCrNi alloy was based on the possibility of $\mathrm{Cr}$ and $\mathrm{Si}$ in amounts around $5 \% \mathrm{wt}$ resisting to high temperature, as small amounts of one can help in the formation of a protective oxide layer for each other ${ }^{4,11}$, as presented in previous studies ${ }^{19}$.

Conventional stainless steels were used for comparison and their compositions, determined by EDS analysis, are also presented in Table 1. All values described are in mass percentage. AISI 304 steel was tested at $850{ }^{\circ} \mathrm{C}$ and AISI 310 steel was tested at 950 and $1050{ }^{\circ} \mathrm{C}$. For AISI 304 steel, nickel and silicon were below the standard recommended values, although EDS technique do not present a high accuracy. Villares Metals kindly provided the conventional stainless steels used for this study.

\subsection{Preparation of samples for oxidation tests}

The FeSiCrNi sample was machined to eliminate the external layers. The FeMnSiCrNiCe sample was hot rolled after casting. The samples were then cut and machined with dimensions that provided a surface area of approximately $5 \mathrm{~cm}^{2}$, given the cyclic oxidation test guidelines published by Nicholls and Bennett ${ }^{20}$. In addition, the samples were bored for placement in the oxidation furnace ( $2 \mathrm{~mm}$ diameter). 
Table 1. Chemical composition in wt \% of the alloys (determined by EDS).

\begin{tabular}{ccccccc}
\hline & \multicolumn{3}{c}{ Alloy composition (\% by mass) } \\
\hline Alloy & Fe & Mn & Si & Cr & Ni & Ce \\
\hline AISI 304 & Balance & 1.94 & 0.31 & 18.75 & 7.71 & - \\
AISI 310 & Balance & 1.82 & 0.81 & 24.41 & 19.27 & - \\
FeSiCrNi & Balance & 0.895 & 5.51 & 4.84 & 3.22 & - \\
FeMnSiCrNiCe & Balance & 13.58 & 5.58 & 9.42 & 3.86 & 0.18 \\
\hline
\end{tabular}

In order to standardize the sample surface, preparation was done using silicon carbide sand paper up to the particle size of \#600. After that, the samples were cleaned by ultrasound using isopropyl alcohol as a cleaning fluid for 2 minutes and were then dried with hot air.

\subsection{Oxidation tests and characterization of cyclically oxidized layers}

The automated furnace used moved itself to expose the samples to high temperature or calm air in cycles. The heat cycle was set for one hour of oven in the high position, with sample exposure to the test air temperature $(850,950$ and $1050{ }^{\circ} \mathrm{C}$ ), then ten minutes of furnace in the low position for exposure to room temperature air to promote natural cooling. Random intervals were selected for removing the test samples from the furnace for weighing. The samples were tested at temperatures of $850^{\circ} \mathrm{C}, 950^{\circ} \mathrm{C}$ and $1050^{\circ} \mathrm{C}$. As reference materials, AISI 304 stainless steel was used for $850{ }^{\circ} \mathrm{C}$ tests and AISI 310 for 950 and $1050{ }^{\circ} \mathrm{C}$ tests.

The characterization of the oxidized layers was performed through Scanning Electron Microscopy (SEM) with a scan voltage of $15 \mathrm{kV}$, X-Ray Diffraction (XRD) with a Cu K-alpha radiation and Energy Dispersive X-Ray Spectroscopy (EDS). Samples for the SEM analyses were cut crosswise, inlayed in bakelite resin, sanded until sandpaper \#1200 and then polished using an alumina solution.

\section{Results and Discussions}

\subsection{Oxidation tests}

After the oxidation tests, graphs and tables were developed relating the mass variations of the samples divided by their respective surface areas versus the number of cycles to which they were subjected at the temperatures of 850,950 and $1050^{\circ} \mathrm{C}$ (Figures 1, 2 and 3).

At $850^{\circ} \mathrm{C}$, as can be seen in Figure 1, the lowest rates of mass gain during the first cycles were of the AISI304 steel and the FeSiCrNi alloy. However, around the $150^{\text {th }}$ cycle, the stainless steel began to suffer spallation. Austenitic steels tend to present oxide detachment more than ferritic ones because they have a coefficient of thermal expansion much higher than that of the oxides, generating higher stress at their interfaces ${ }^{21}$. The small mass gain observed for FeSiCrNi alloy indicates that the small chromium amount

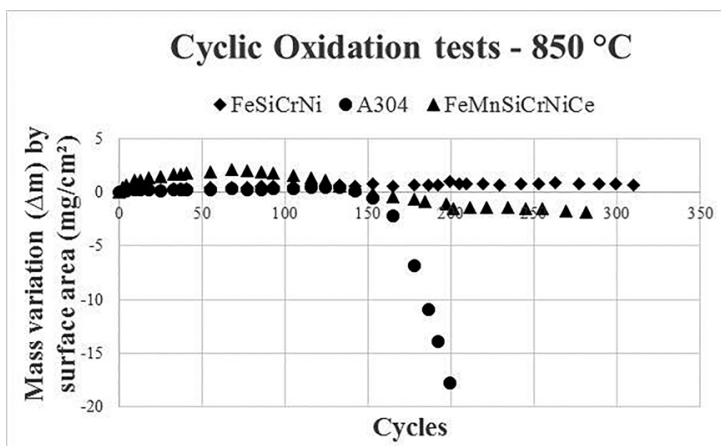

Figure 1. Mass variation by superficial area versus number of cycles in cyclic oxidation test at $850^{\circ} \mathrm{C}$.

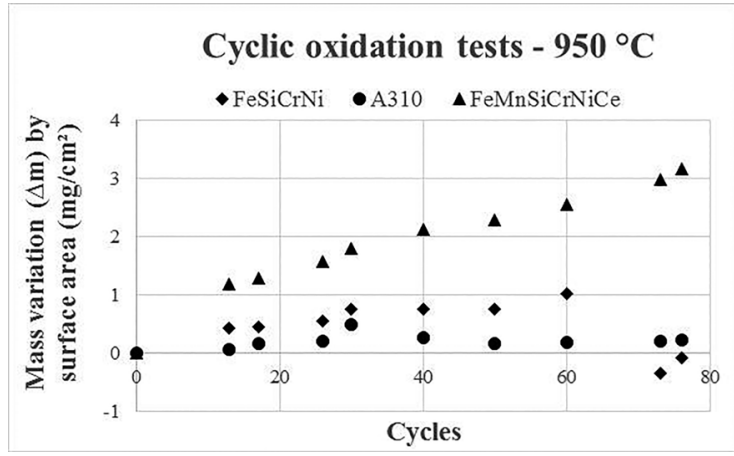

Figure 2. Mass variation by superficial area versus number of cycles in cyclic oxidation test at $950^{\circ} \mathrm{C}$.

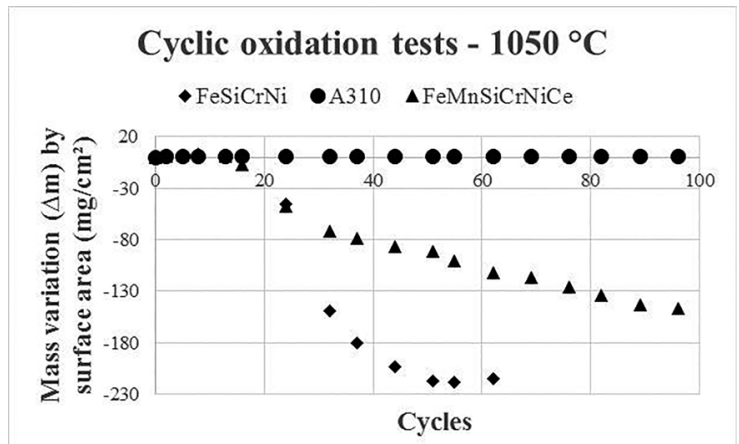

Figure 3. Mass variation by surface area versus number of cycles in cyclic oxidation test at $1050^{\circ} \mathrm{C}$.

was compensated by silicon addition. Huntz et al. ${ }^{4}$ achieved similar behavior adding $2 \mathrm{wt} \% \mathrm{Si}$ in iron- $9 \% \mathrm{Cr}$ steels. The mechanism observed for them was the formation of a silica 
layer, reducing oxygen activity and allowing formation of a chromia layer above, without iron oxide formation. The FeMnSiCrNiCe alloy presented higher rate of mass gain compared to the other samples. After approximately 70 cycles, the alloy started to suffer spallation, but at a smaller rate compared to the AISI 304 steel. In a previous study ${ }^{10}$, anomalous behavior in a FeMnSiCrNi alloy was noticed: new mass gain after spallation at 800 and $900{ }^{\circ} \mathrm{C}$ (with a lower rate than initial mass gain), which help to understand the decrease in mass loss rate after 200 cycles in the present study. As reported by Ma et al. ${ }^{9}$, the high mass gains in the first cycles in which the alloys presented mass gains ten times higher than AISI steel 304 at $800^{\circ} \mathrm{C}$, can be attributed to the presence of manganese.

At $950{ }^{\circ} \mathrm{C}$, as conveyed in Figure 2, stainless steel was the material that presented the best behavior and the FeMnSiCrNiCe alloy did not present spallation during the 76 cycles tested. As in $850{ }^{\circ} \mathrm{C}$, it was noticed that the presence of $\mathrm{Mn}$ in the alloy generated mass gain faster than in the FeSiCrNi alloy. However, at around 70 cycles, the FeSiCrNi alloy presented a mass loss that can be explained by the low silicon and chromium contents, which may not have been sufficient to form a protective layer in this composition. This may have induced early formation of iron oxide that may have been responsible for early spallation.

At $1050{ }^{\circ} \mathrm{C}$ (Figure 3), AISI 310 stainless steel was the sample that presented the best result, with a small mass gain and without spallation that can be explained by the high amount of chromium in the steel composition. Oppositely, the FeMnSiCrNiCe and FeSiCrNi alloys presented mass losses shortly after the $20^{\text {th }}$ cycle. It may be suggested that the formed oxides were not able to protect the material and generated continuous spallation, but at a lower mass loss rate to FeMnSiCrNiCe than the FeSiCrNi alloy.

\subsection{Characterization of cyclically oxidized layers - SEM, EDS and XRD}

\subsubsection{FeSiCrNi}

Figure 4 shows the SEM of the cross sections of FeSiCrNi alloy samples at the temperatures of 850,950 and $1050^{\circ} \mathrm{C}$ and the EDS analyses for the same alloys. X-ray diffraction analyses were also performed on the $\mathrm{FeSiCrNi}$ samples cyclically tested at 850,950 and $1050{ }^{\circ} \mathrm{C}$ and their results are shown in Figure 5.

At 850 and $950{ }^{\circ} \mathrm{C}$ (Figure 4), a magnification of $200 \mathrm{x}$ was used and for the temperature of $1050^{\circ} \mathrm{C}$ a magnification of 30x was used in which it was already possible to identify the oxidized layer in SEM. The high thickness showed at $1050{ }^{\circ} \mathrm{C}$ is a consequence of continuous spallation that caused breakaway oxidation, mass loss and iron oxides formation. The horizontal cracks observed in Figure 4 (FeSiCrNi $-1050^{\circ} \mathrm{C}$ ) show the brittleness of oxide/oxide interfaces, suggesting mass loss by oxide layer delamination.
Safikhani et al. ${ }^{22}$ observed similar delamination behavior in ferritic stainless steel occurring between internal $\mathrm{Cr}_{2} \mathrm{O}_{3}$ and external $\mathrm{Mn} / \mathrm{Cr}$ spinel and $\mathrm{TiO}_{2}$.

For the FeSiCrNi alloy oxidized at 850,950 and $1050{ }^{\circ} \mathrm{C}$, the EDS analysis allowed the identification of $\mathrm{Fe}, \mathrm{Cr}$ and Mn elements present in the oxide layer and at the metal/ oxide interface. It is important to mention the presence of alloying elements in the samples analyzed. The existence of $\mathrm{Cr}$ in the oxidized layer of each temperature was observed. High concentrations of $\mathrm{Fe}$ in the oxidized layer were also detected (for $1050{ }^{\circ} \mathrm{C}$ ), meaning there was iron oxide present in the oxidized layer. The other elements found in the layer, chromium and manganese, are common in $\mathrm{Fe}-\mathrm{Cr}$ alloys ${ }^{23}$. The manganese found in the FeSiCrNi alloy probably came from the steel 1010, which was used as an iron balance during the alloy melting process.

XRD results (Figure 5) presents that the oxides formed were rich in $\mathrm{Cr}$ and $\mathrm{Mn}$. They were identified as $\mathrm{MnCr}_{2} \mathrm{O}_{4}$ and $\mathrm{Mn}_{2} \mathrm{O}_{3}$ at $850{ }^{\circ} \mathrm{C}$ and $\mathrm{MnCr}_{2} \mathrm{O}_{4}$ at $950{ }^{\circ} \mathrm{C}$. Additionally, at $950^{\circ} \mathrm{C}$, due to the oxide thickness and the oxide spallation, ferrite peaks $(\alpha-\mathrm{Fe})$ were identified in the diffractogram from the alloy's ferritic matrix. At $1050^{\circ} \mathrm{C}, \mathrm{Fe}_{2} \mathrm{O}_{3}$ and $\mathrm{Fe}_{3} \mathrm{O}_{4}$ oxides were found, suggesting that the chromium was not sufficient in ensuring layer protection on the surface alloy. An Fe-17Cr alloy with small amounts of Mn was observed by Hua et al. ${ }^{23}$. They reported $\mathrm{MnCr}_{2} \mathrm{O}_{4}$ formation for alloys with at least $0.5 \mathrm{wt} \%$ of $\mathrm{Mn}$ and $\mathrm{Mn}_{2} \mathrm{O}_{3}$ for an alloy with at least $2.0 \mathrm{wt} \%$ of $\mathrm{Mn}$. They observed also that oxidation rate and manganese content are correlated. As the manganese content was increased, the oxidation rate also increased. On the other hand, for high temperatures (1050 to $\left.1250{ }^{\circ} \mathrm{C}\right) \mathrm{a}$ cobalt based alloy with manganese additions ( 0.5 to $2 \mathrm{wt} \%$ ) presented better behavior (less mass gain), due to the higher stability of $\mathrm{MnCr}_{2} \mathrm{O}_{4}$ than $\mathrm{Cr}_{2} \mathrm{O}_{3}$ in this conditions ${ }^{24}$.

\subsubsection{FeMnSiCrNiCe}

Figure 6 shows the cross-section of FeMnSiCrNiCe alloy samples, oxidized at 850,950 and $1050{ }^{\circ} \mathrm{C}$ and their EDS maps. In all samples, it was possible to identify and visualize the oxidized layer with a 200x magnification. It is possible to see in these pictures that the oxidized layer is thicker than the one presented by the FeSiCrNi alloy (Figure 4 - for 850 and $950{ }^{\circ} \mathrm{C}$ ) and the cause of this mass gain is the Mn content of the alloy composition.

Figure 6 also shows the cross-section of the FeMnSiCrNiCe oxidized at 850,950 and $1050^{\circ} \mathrm{C}$ and the concentration of the most representative chemical elements: $\mathrm{Fe}, \mathrm{Cr}$ and Mn. When evaluating the EDS results obtained with the FeMnSiCrNiCe alloy, the high concentration of manganese in the oxidized layer is clearly visible and can be explained by the high avidity of the manganese by the oxygen ${ }^{5}$. For the three temperatures evaluated, a high concentration of chromium at the metal oxide interface and a low concentration of $\mathrm{Fe}$ in the oxidized layer was also notice. 

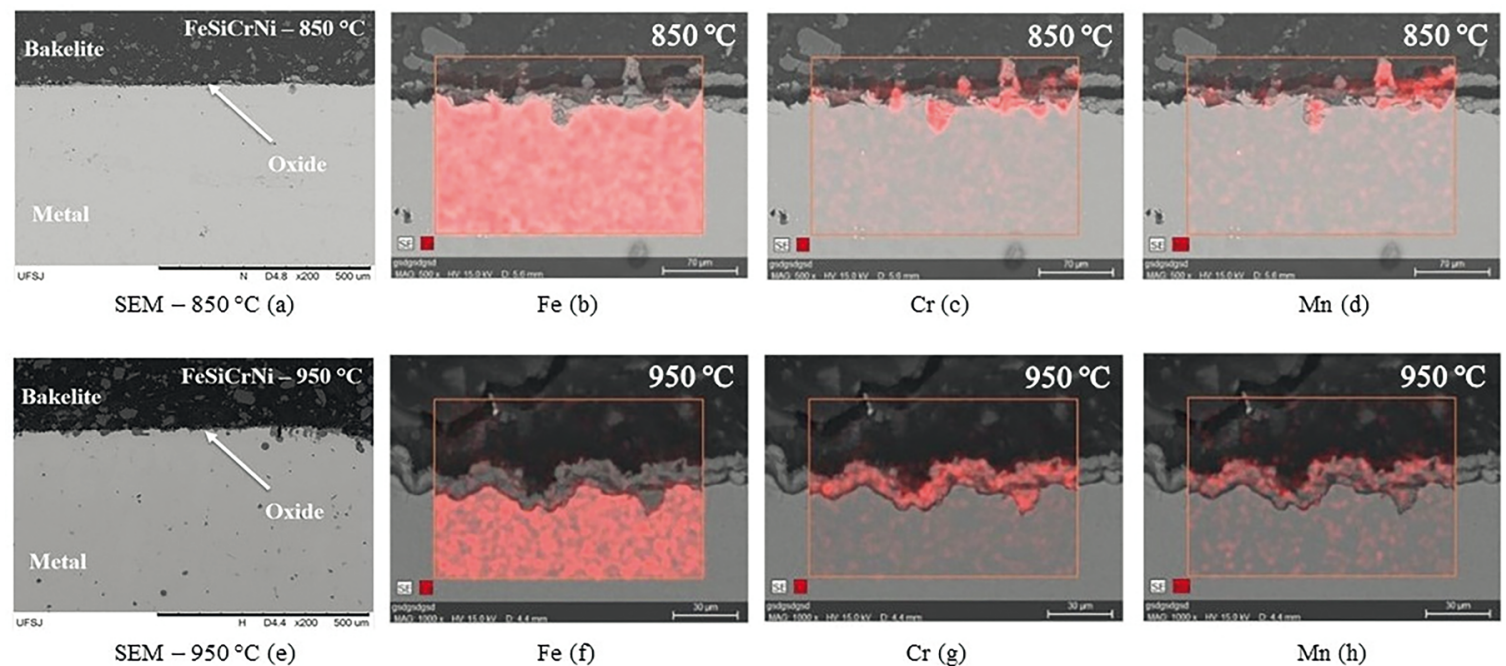

$\mathrm{Fe}(\mathrm{f})$

$\mathrm{Cr}(\mathrm{g})$

$\mathrm{Mn}(\mathrm{h})$
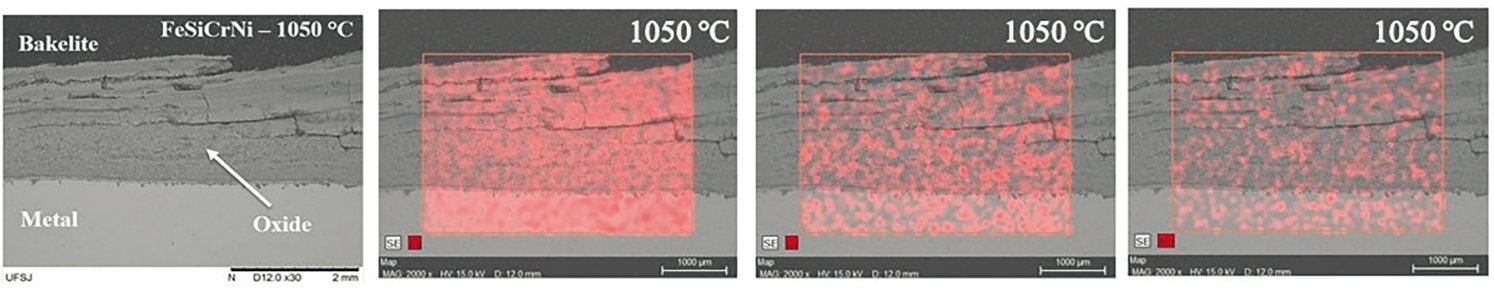

SEM $-1050^{\circ} \mathrm{C}(\mathrm{i})$

$\mathrm{Fe}(\mathrm{j})$

$\mathrm{Cr}(\mathrm{k})$

$\operatorname{Mn}(1)$

Figure 4. SEM/EDS of cross section of the FeSiCrNi alloy after cyclic oxidation at 850,950 and $1050{ }^{\circ} \mathrm{C}$.

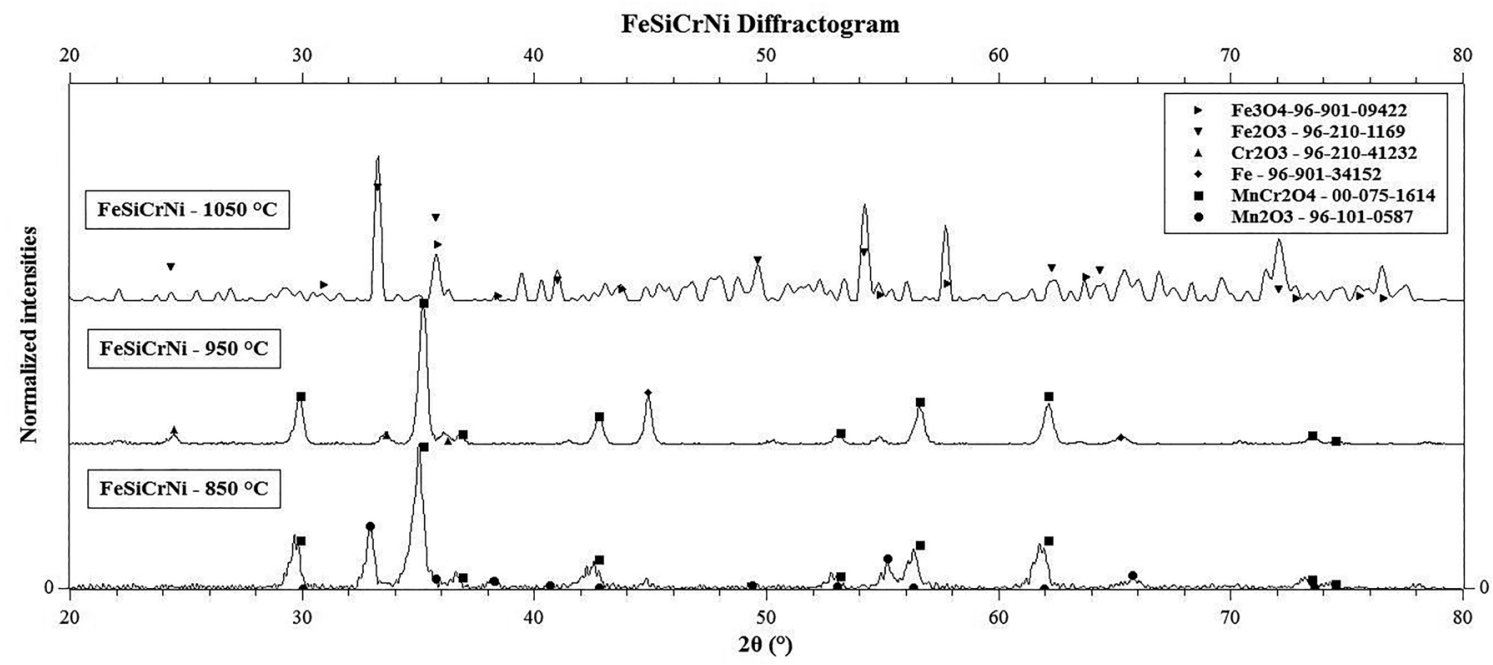

Figure 5. XRD oxidized layer diffractogram after 850,950 and $1050{ }^{\circ} \mathrm{C}$ tests -FeSiCrNi.

The XRD results are shown in Figure 7 and the presence of manganese was evident in the oxides formed on the sample's top surface. At $850^{\circ} \mathrm{C}, \mathrm{Mn}_{2} \mathrm{O}_{3}$ and a spinel of $\mathrm{Cr}-\mathrm{Mn}$ as $\mathrm{MnCr}_{2} \mathrm{O}_{4}$ were found and at $950{ }^{\circ} \mathrm{C}, \mathrm{Mn}_{3} \mathrm{O}_{4}$ was identified. At $1050{ }^{\circ} \mathrm{C} \mathrm{MnCr}_{2} \mathrm{O}_{4}$ was noticed, similarly to $850{ }^{\circ} \mathrm{C}$ and along with peaks of ferrite $(\alpha-\mathrm{Fe})$.

Although the EDS results show a presence of chromium at metal-oxide interface, the identification of just these Mn-rich oxides can be explained by the oxide layer thickness, as mentioned by Ma et al. ${ }^{9}$. Furthermore, in their research with FeMnSiCrNi alloys, Ma et al. ${ }^{9}$ found three manganese rich oxides in the oxidized layer after 100 hours of exposure at $800^{\circ} \mathrm{C}: \mathrm{Mn}_{2} \mathrm{O}_{3}$ in the outermost region, $\mathrm{Mn}_{3} \mathrm{O}_{4}$ in the middle of the layer and $\mathrm{MnCr}_{2} \mathrm{O}_{4}$ in the innermost portion of the layer. Additionally, chromium oxides were not found at the top surface of samples for an Fe-14.3Mn-5.6Si-8.2Cr-5Ni 


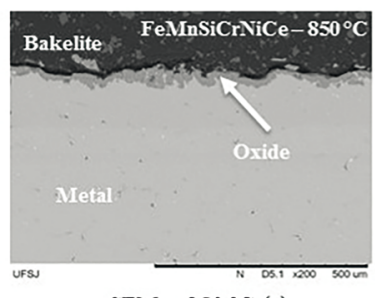

$\mathrm{SEM}-850^{\circ} \mathrm{C}$ (a)

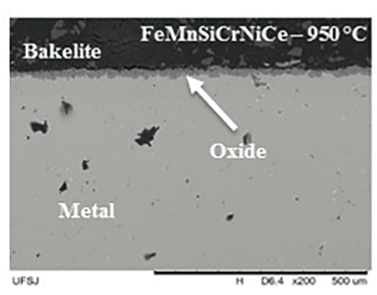

$\mathrm{SEM}-950^{\circ} \mathrm{C}(\mathrm{e})$

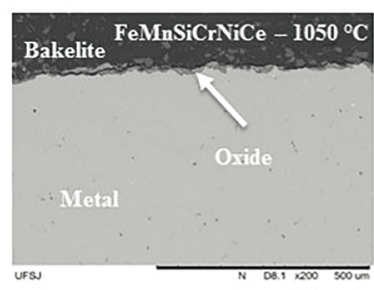

SEM $-1050^{\circ} \mathrm{C}$ (i)

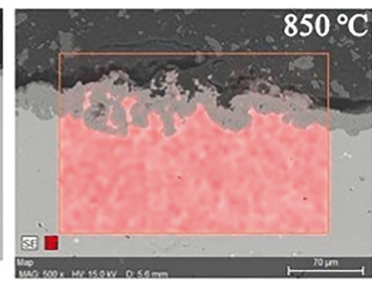

$\mathrm{Fe}$ (b)

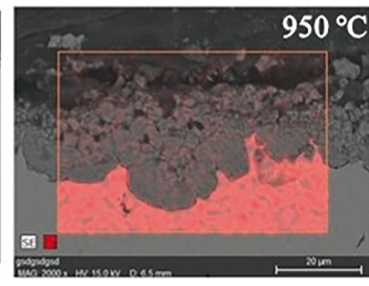

$\mathrm{Fe}(\mathrm{f})$

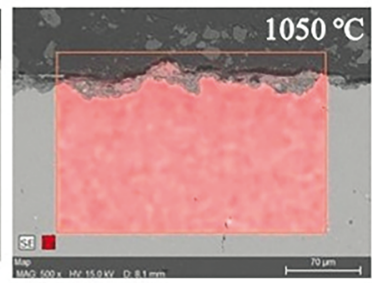

$\mathrm{Fe}$ (j)

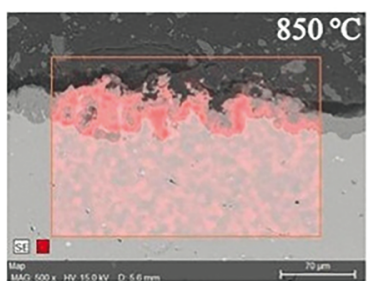

$\mathrm{Cr}$ (c)

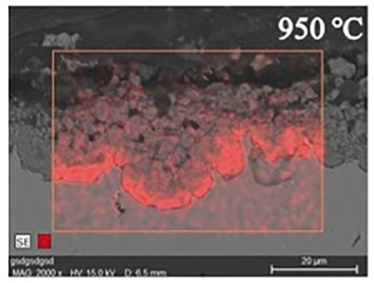

Cr (g)

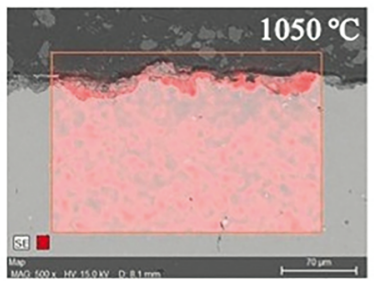

$\mathrm{Cr}(\mathrm{k})$

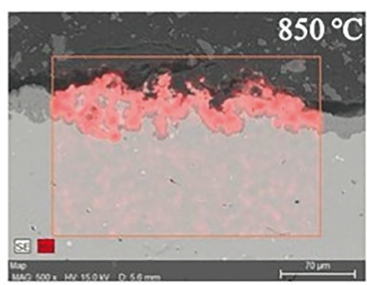

$\mathrm{Mn}(\mathrm{d})$

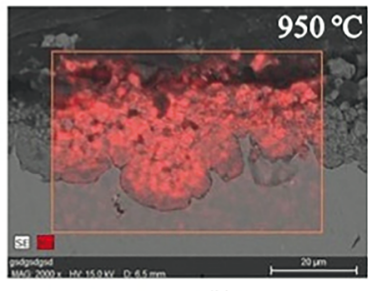

Mn (h)

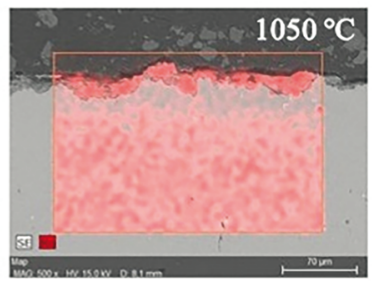

Mn (1)

Figure 6. SEM/EDS of cross section of the FeMnSiCrNiCe alloy after cyclic oxidation at 850,950 and $1050{ }^{\circ} \mathrm{C}$.

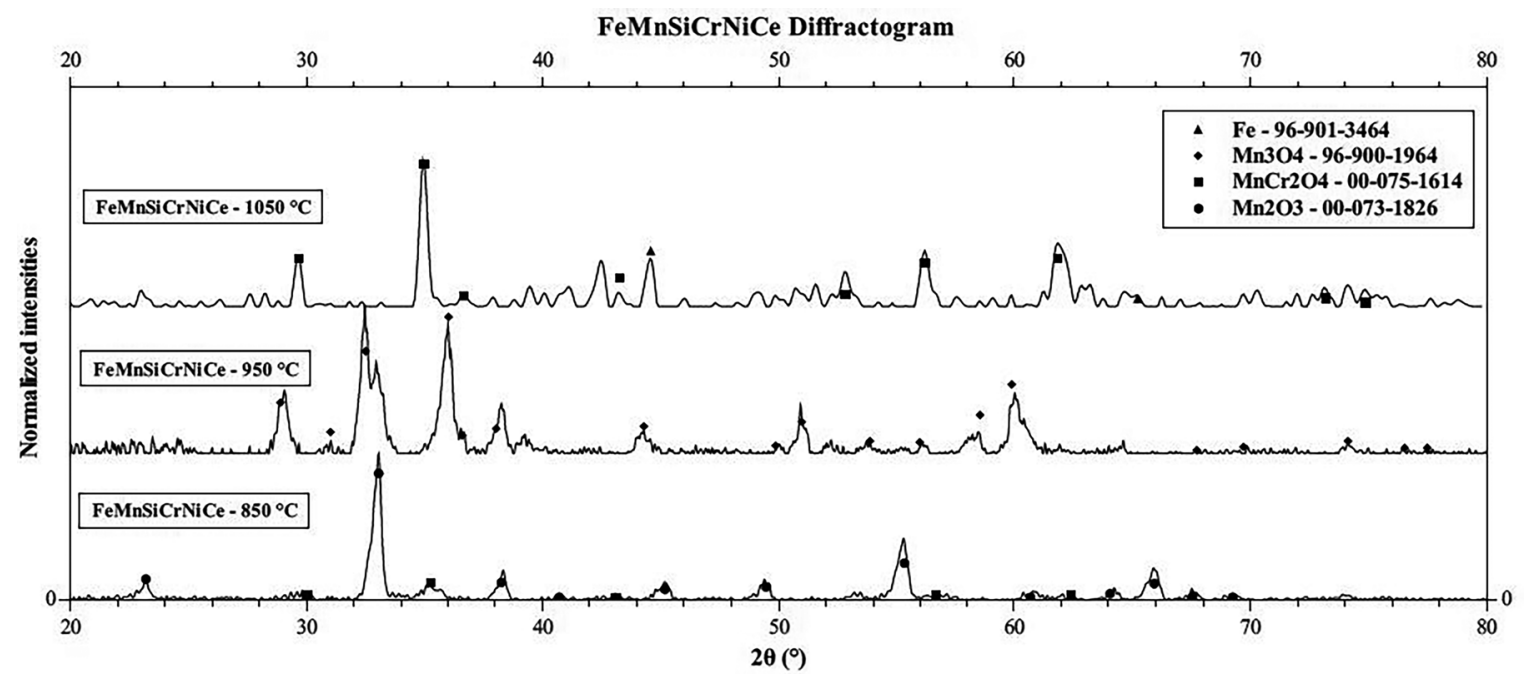

Figure 7. XRD oxidized layer diffractogram after 850,950 and $1050{ }^{\circ} \mathrm{C}$ tests $-\mathrm{FeMnSiCrNiCe}$.

alloy oxidized at $800{ }^{\circ} \mathrm{C}$. Finally, they also proposed the possibility of silica formation by Thermocalc, but did not observe this oxide, which normally forms at metal-oxide interface in nanometric scale.

\subsection{Oxidation kinetics}

Figures 8 and 9 illustrate the adjustments made to find the values of parabolic mass gain coefficient $\mathrm{k}_{\mathrm{p}}$ for the $\mathrm{FeSiCrNi}$ and $\mathrm{FeMnSiCrNiCe}$ alloys; Figures 8 and 9, respectively. In both cases, the points found before the start of detachment were used. The points when spallation started are not shown in the graphic. The results obtained suggest that there is a mass variation trend with a parabolic rate for both alloys and all temperatures tested.

Table 2 shows the values found for $\mathrm{k}_{\mathrm{p}}$ (mass gain coefficient), at the test temperatures for all the alloys 


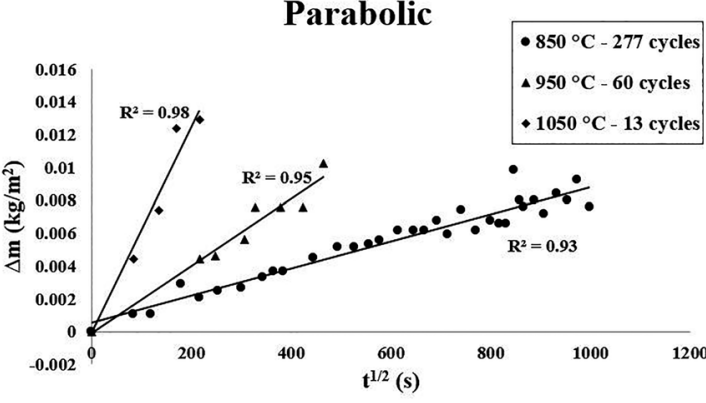

Figure 8. Parabolic kinetic determination for the FeSiCrNi alloy.

\section{Parabolic}

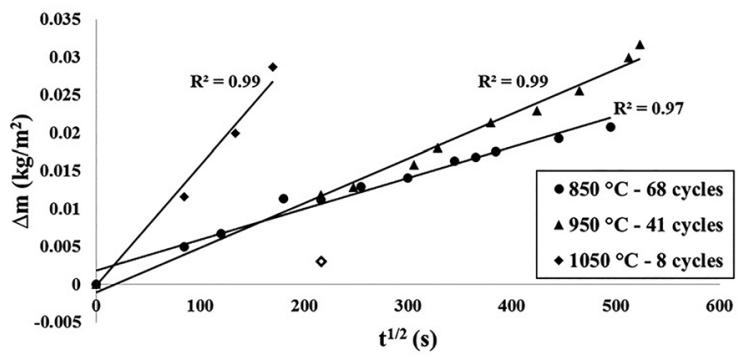

Figure 9. Parabolic kinetic determination for the $\mathrm{FeMnSiCrNiCe}$ alloy.

tested. It should also be mentioned that the value found for $\mathrm{FeSiCrNi}$ alloy was lower than the result obtained for AISI 304 steel at a temperature of $850^{\circ} \mathrm{C}$. The AISI 310 presented lower $\mathrm{k}_{\mathrm{p}}$ values than all material at $950^{\circ} \mathrm{C}$. For $1050^{\circ} \mathrm{C}$, the FeSiCrNi alloy presented $\mathrm{k}_{\mathrm{p}}$ smaller than AISI 310 , but start to spall with small number of cycles. Nevertheless, the AISI 310 steel used at temperatures of 950 and $1050^{\circ} \mathrm{C}$ showed higher values of $\mathrm{k}_{\mathrm{p}}$ than those found by Baleix, Bernhart and Lours ${ }^{21}$ for austenitic FeCrNi steels heat resistant (24$29 \% \mathrm{Cr}$ and $33-52 \% \mathrm{Ni}$ ). The authors found $1.88 \times 10^{-12}$ and $2.29 \times 10^{-11} \mathrm{~kg}^{2} / \mathrm{m}^{4} . \mathrm{s}$ for temperatures of 900 and $1000{ }^{\circ} \mathrm{C}$, but the higher nickel content applied may have affected the oxidation resistance of the alloy.

Similar values of $\mathrm{k}_{\mathrm{p}}$ were also found by other studies ${ }^{4,25}$. Huntz et al. ${ }^{4}$ studied similar alloys with contents of 2, 3 and $4 \%$ of silicon and $9 \% \mathrm{Cr}$, in two different atmospheres. In the first atmosphere, the oxygen was at partial pressure of 1 atm and the second was lower oxygen pressure atmosphere with a mix of $\mathrm{Ar}-\mathrm{H}_{2}-\mathrm{H}_{2} \mathrm{O}$. Moreover, in the first atmosphere at $950{ }^{\circ} \mathrm{C}$, all the values ranged from 1.2 and $1.9 \times 10^{-10} \mathrm{~kg}^{2} / \mathrm{m}^{4} . \mathrm{s}$ except for the alloy with $3 \% \mathrm{Si}$ in the higher oxygen pressure atmosphere, that showed $\mathrm{k}_{\mathrm{p}}$ at $6.4 \times 10^{-10} \mathrm{~kg}^{2} / \mathrm{m}^{4} \cdot \mathrm{s}^{4}$. Nguyen et al. ${ }^{25}$ found higher values than those presented in this study for Fe-9Cr-1 Mn and Fe-9Cr-2Mn alloys isothermally oxidized at the temperature of $818^{\circ} \mathrm{C}$ in an $\mathrm{Ar}-20 \mathrm{CO}_{2}$ (volume) mixture with a linear flow of $2 \mathrm{~cm} / \mathrm{s}$ and a pressure of $1 \mathrm{~atm}$. The atmosphere used was different from that used in this research and this fact suggests that the mass gain coefficient to be higher because of its more aggressive atmosphere.

The chromium content used by Huntz et al. ${ }^{4}$ in the above cited research was larger than the content used in the present study. Hence, the formed layer provided a better protection and lower mass gain coefficients for the alloys than the results obtained in this research. A greater amount of $\mathrm{Cr}$ ensures the formation of a protective oxide on the surface of the alloy and considerably reduces mass gain. The study of Nguyen et al. ${ }^{25}$ also contained a higher chromium content, however, the atmosphere used was more aggressive and such condition may have accelerated the oxidation process by increasing the mass gain coefficients of the alloys.

The $\mathrm{FeMnSiCrNiCe}$ alloy also showed $\mathrm{k}_{\mathrm{p}}$ values within the range found by de Sousa Malafaia and de Oliveira ${ }^{10}$ for an alloy with a composition similar to that tested in this study (Fe-17Mn-5Si-10Cr-4Ni-0.59V-0.14C). In their study, the values of $\mathrm{k}_{\mathrm{p}}$ were between $9.95 \times 10^{-10}$ and $6.76 \times 10^{-9} \mathrm{~kg}^{2} / \mathrm{m}^{4} . \mathrm{s}$, at temperatures of 800,900 and $1000{ }^{\circ} \mathrm{C}$. Ma et al..$^{9}$ found that an $\mathrm{Fe}-14.3 \mathrm{Mn}-5.6 \mathrm{Si}-8.2 \mathrm{Cr}-5 \mathrm{Ni}$ alloy at a temperature of $800{ }^{\circ} \mathrm{C}$ and using isothermal tests for evaluation had a $\mathrm{k}_{\mathrm{p}}$ value approximately of $2.55 \times 10^{-9} \mathrm{~kg}^{2} / \mathrm{m}^{4} . \mathrm{s}$, which is a higher value than the one obtained to $8500^{\circ} \mathrm{C}$ in the present study $\left(1.65 \times 10^{-9} \mathrm{~kg}^{2} / \mathrm{m}^{4} . \mathrm{s}\right)$. There are some explanations for the variation of these values. The first are the different compositions applied in the various studies. In the Ma et al. ${ }^{9}$ study, the chromium content used was lower than that applied in this study and previous studies, which indicate a greater stabilization of the oxidized layer through the higher amount of chromium. The second rationale is the way the test was performed in Ma et al. ${ }^{9}$ because of the more aggressive stresses generated to the tested material by the cyclic process.

The cerium used in the alloy also probably helped to decrease the $\mathrm{k}_{\mathrm{p}}$ values. Considering $\mathrm{E}_{\mathrm{a}}$ and $\mathrm{k}_{0}$ values calculated by de Sousa Malafaia and de Oliveira ${ }^{10}$ for an FeMnSiCrNi alloy without cerium, the value of $k_{p}$ to $950{ }^{\circ} \mathrm{C}$ would be $4.6 \times 10^{-9} \mathrm{~kg}^{2} / \mathrm{m}^{4} . \mathrm{s}$, higher than observed here $\left(\mathrm{kp}=3.48 \times 10^{-9} \mathrm{~kg}^{2} / \mathrm{m}^{4} . \mathrm{s}\right.$ for $\left.950^{\circ} \mathrm{C}\right)$. Disregarding

Table 2. Values of $\mathrm{k}_{\mathrm{p}}$ for the samples tested.

\begin{tabular}{ccccccc}
\hline \multirow{2}{*}{ Material } & \multicolumn{5}{c}{$\mathrm{k}_{\mathrm{p}}\left(\mathrm{kg}^{2} / \mathrm{m}^{4} . \mathrm{s}\right)$} \\
\cline { 2 - 7 } & $850^{\circ} \mathrm{C}$ & Intervals & $950^{\circ} \mathrm{C}$ & Intervals & $1050^{\circ} \mathrm{C}$ & Intervals \\
\hline AISI 304 steel & $7.84 \times 10^{-11}$ & $0-13$ Cycles & - & - & - & - \\
AISI 310 steel & - & - & $3.6 \times 10^{-11}$ & $0-26$ Cycles & $4.9 \times 10^{-9}$ & $0-5$ Cycles \\
FeSiCrNi alloy & $6.85 \times 10^{-11}$ & $0-277$ Cycles & $4 \times 10^{-10}$ & $0-60$ Cycles & $3.6 \times 10^{-9}$ & $0-13$ Cycles \\
FeMnSiCrNiCe alloy & $1.65 \times 10^{-9}$ & $0-68$ Cycles & $3.48 \times 10^{-9}$ & $0-76$ Cycles & $4.00 \times 10^{-8}$ & $0-8$ Cycles \\
\hline
\end{tabular}


other composition differences, the cerium addition is related to some phenomena that can corroborate to this low value of $\mathrm{k}_{\mathrm{p}}$. The first is the grain refinement, which helps the chromium diffusivity and enhances the enrichment of this element in oxide layer ${ }^{17}$. Secondly, in cerium presence, the oxidation mechanism can change, decreasing cation diffusivity across oxide layer, and promoting oxide layer increase only by anion diffusion ${ }^{26}$, also observed to other rare earths additions ${ }^{18}$. Finally, as Mn oxides and $\mathrm{Cr}-\mathrm{Mn}$ spinel are p-type semiconductor ${ }^{9,27}$ and as the $\mathrm{Mn}$ and $\mathrm{Cr}$ assume $\mathrm{Mn}^{+3}, \mathrm{Mn}^{+2}$ and $\mathrm{Cr}^{+3}$ valences ${ }^{28}$, the addition of cerium, presenting $\mathrm{Ce}^{+4}$ valence, according to Wagner-Hauffe rules should increase the oxidation rate ${ }^{29}$. On the other hand, some spinels can change to a n-type conductor behavior when doped of other specimens, as the case of $\mathrm{Mg}_{1,5} \mathrm{Cr}_{1,5} \mathrm{O}_{4}$ (p-type) when doped with $\mathrm{Ti}, \mathrm{Mg}_{1,5} \mathrm{Ti}_{0,5} \mathrm{CrO}_{4}$ (n-type) $)^{27,30}$. Rare earth and $\mathrm{NiO}$ additions in $\mathrm{Cr}_{2} \mathrm{O}_{3}$ forming steel also changed the conduction of this oxide from p-type to n-type in low oxygen pressures, reducing the mass gain during high temperature oxidation ${ }^{31}$. Thus, if this effect occurred in the present study, the valence of $\mathrm{Ce}^{+4}$ could contribute to reduce the mass gain, considering the Wagner-Hauffe rules. However, some authors demonstrated that these rules present some inaccuracies and consider that for complex systems, other effects as ions solubility and defects in the oxide layer should be considered ${ }^{29,32}$.

The activation energy was also calculated for the two tested alloy compositions. The calculated value for the $\mathrm{FeSiCrNi}$ alloy was $243 \mathrm{KJ} / \mathrm{mol}$. This value is close to that found by Baleix et al. ${ }^{21}$ for austenitic stainless steels of $\mathrm{FeCrNi}$, in which $247 \mathrm{KJ} / \mathrm{mol}$ was found for $\mathrm{Cr}_{2} \mathrm{O}_{3}$ formation. For the FeMnSiCrNiCe alloy, the value found was $133.8 \mathrm{KJ} / \mathrm{mol}$. This value is higher than that found by de Sousa Malafaia and De Oliveira ${ }^{10}$ for an Fe-17Mn-5Si-10Cr-4Ni-0.59V-0.14C alloy $(109.0 \mathrm{KJ} / \mathrm{mol})$. This activation energy is explained most likely by the composition of the studied alloy, which contained cerium and a lower amount of manganese. Therefore, it can be said that a greater amount of energy is required for the activation of the oxidation process.

\section{Conclusions}

This research demonstrated that the best results obtained for the oxidation tests were with an FeSiCrNi alloy at a temperature of $850^{\circ} \mathrm{C}$ and AISI 310 steel at temperatures of 950 and $1050^{\circ} \mathrm{C}$. The $\mathrm{FeSiCrNi}$ alloy formed $\mathrm{Mn} / \mathrm{Cr}$ protective oxide as observed in the diffractogram of the alloy, but due to the low content of silicon and chromium in the alloy, the grown of new protective layer was not possible after some spallation at 950 and $1050{ }^{\circ} \mathrm{C}$. At the highest temperature, the spallation allowed the formation of iron oxides that may have contributed to high mass loss. For the FeMnSiCrNiCe alloy, manganese oxides were present in all the temperatures tested. As expected, it was the alloy that had the highest mass gain, which can be explained by the Mn preferential oxidation. At the temperatures of 850 and $950^{\circ} \mathrm{C}$, the FeMnSiCrNiCe alloy showed good behavior but at $1050^{\circ} \mathrm{C}$, it suffered rapid spallation. Despite some spallation in high temperatures, the amount of silicon at $\mathrm{FeSiCrNi}$ alloy was enough to provided a small value of $\mathrm{k}_{\mathrm{p}}$, showing the potential of this alloy for temperatures around $850{ }^{\circ} \mathrm{C}$. Considering FeMnSiCrNiCe alloy, the $\mathrm{k}_{\mathrm{p}}$ values were smaller than those already published, showing the effect of cerium in decrease the oxidation rate of FeMnSiCrNi shape memory alloys.

\section{Acknowledgements}

The authors would like to thank Villares Metals for providing the stainless steels.

\section{References}

1. Atkinson A. Transport processes during the growth of oxide films at elevated temperature. Reviews of Modern Physics. 1985;57(2):437-470. DOI: 10.1103/RevModPhys.57.437

2. Smialek JL. A deterministic interfacial cyclic oxidation spalling model. Acta Materialia. 2003;51(2):469-483. DOI: 10.1016/ S1359-6454(02)00430-5

3. Chen RY, Yeun WYD. Review of the High-Temperature Oxidation of Iron and Carbon Steels in Air or Oxygen. Oxidation of Metals. 2003;59(5-6):433-468. DOI: 10.1023/A:1023685905159

4. Huntz A, Bague V, Beauplé G, Haut C, Sévérac C, Lecour P, et al. Effect of silicon on the oxidation resistance of $9 \% \mathrm{Cr}$ steels. Applied Surface Science. 2003;207(1-4):255-275. DOI: 10.1016/S0169-4332(02)01505-2

5. Coccia Lecis G, Lenardi C, Sabatini A. The effect of Mn-depleted surface layer on the corrosion resistance of shape memory FeMn-Si-Cr alloys. Metallurgical and Materials Transactions A. 1997;28:1219-1222. DOI: 10.1007/s11661-997-0287-z

6. Otsuka H, Yamada H, Maruyama T, Tanahashi H, Matsuda S, Murakami M. Effects of Alloying Additions on Fe-Mn-Si Shape Memory Alloys. ISIJ International. 1990;30(8):674-679. DOI: 10.2355/isijinternational.30.674

7. Della Rovere CA, Alano JH, Otubo J, Kuri SE. Corrosion behavior of shape memory stainless steel in acid media. Journal of Alloys and Compounds. 2011;509(17):5376-5780. DOI: 10.1016/j.jallcom.2011.02.051

8. Della Rovere CA, Alano JH, Silva R, Nascente PAP, Otubo J, Kuri SE. Characterization of passive films on shape memory stainless steels. Corrosion Science. 2012;57:154-161. DOI: 10.1016/j.corsci.2011.12.022

9. Ma R, Peng H, Wen Y, Zhang L, Zhao K. Oxidation behavior of an austenitic stainless FeMnSiCrNi shape memory alloy. Corrosion Science. 2013;66:269-277. DOI: 10.1016/j.corsci.2012.09.029

10. Malafaia AMS, de Oliveira MF. Anomalous cyclic oxidation behaviour of a Fe-Mn-Si-Cr-Ni shape memory alloy. Corrosion Science. 2017;119:112-117. DOI: 10.1016/j.corsci.2017.02.026 
11. Atkinson A. A theoretical analysis of the oxidation of Fe-Si alloys. Corrosion Science. 1982;22(2):87-102. DOI: 10.1016/0010938X(82)90071-3

12. Malafaia AMS, Milan MT, Omar M, Muñoz Riofano RM, de Oliveira MF. Oxidation and abrasive wear of $\mathrm{Fe}-\mathrm{Si}$ and Fe-Al intermetallic alloys. Journal of Materials Science. 2010;45(19):5393-5397. DOI: 10.1007/s10853-010-4591-4

13. Castro DB V, Rossino LS, Malafaia AMS, Angeloni M, Maluf O. Influence of Annealing Heat Treatment and $\mathrm{Cr}, \mathrm{Mg}$, and $\mathrm{Ti}$ Alloying on the Mechanical Properties of High-Silicon Cast Iron. Journal of Materials Engineering and Performance. 2011;20(7):1346-1354. DOI: 10.1007/s11665-010-9733-y

14. Kim BH, Shin JS, Lee SM, Moon BM. Improvement of tensile strength and corrosion resistance of high-silicon cast irons by optimizing casting process parameters. Journal of Materials Science. 2007;42(1):109-117. DOI: 10.1007/s10853-006-1081-9

15. Seon FM. Rare earths for materials corrosion protection. Journal of the Less Common Metals. 1989;148(1-2):73-78. DOI: 10.1016/0022-5088(89)90012-X

16. Rhys-Jones TN, Grabke HJ. Use of cerium and cerium oxide additions to improve high temperature oxidation behaviour of Fe-Cr alloys. Materials Science and Technology. 1988;4(5):446454. DOI: $10.1179 / \mathrm{mst} .1988 .4 .5 .446$

17. Li X, Shu J, Chen L, Bi H. Effect of Cerium on High-Temperature Oxidation Resistance of 00Cr17NbTi Ferritic Stainless Steel. Acta Metallurgica Sinica (English Letters). 2014;27(3):501507. DOI: 10.1007/s40195-014-0079-6

18. Pillis MF, de Araújo EG, Ramanathan LV. Effect of rare earth oxide additions on oxidation behavior of AISI 304L stainless steel. Materials Research. 2006;9(4):375-379. DOI: 10.1590/ S1516-14392006000400006

19. Malafaia AMS, Milan MT, Riofano RMM, MalufO, de Oliveira MF. Cyclic oxidation of Fe-Si-Cr and Fe-Mn-Si-Cr-Ni alloys. In: IMMC $15^{\text {th }}$ International Metallurgy \& Materials Congress; 2010 Nov 11-13; Istambul, Turkey. p. 1293-1297.

20. Nicholls JR, Bennett MJ. Cyclic oxidation - guidelines for test standardisation, aimed at the assessment of service behaviour. Materials at High Temperatures. 2000;17(3):413-428. DOI: 10.1179/mht.2000.17.3.005

21. Baleix S, Bernhart G, Lours P. Oxidation and oxide spallation of heat resistant cast steels for superplastic forming dies. Materials Science and Engineering: A. 2002;327(2):155-166. DOI: $10.1016 / \mathrm{S} 0921-5093(01) 01529-5$
22. Safikhani A, Esmailian M, Tinatiseresht T, Darband GB. High temperature cyclic oxidation behavior of ferritic stainless steel with addition of alloying elements $\mathrm{Nb}$ and $\mathrm{Ti}$ for use in SOFCs interconnect. International Journal of Hydrogen Energy. 2016;41(14):6045-6052. DOI: 10.1016/j.ijhydene.2016.01.090

23. Hua B, Kong Y, Zhang W, Pu J, Chi B, Jian L. The effect of $\mathrm{Mn}$ on the oxidation behavior and electrical conductivity of $\mathrm{Fe}-17 \mathrm{Cr}$ alloys in solid oxide fuel cell cathode atmosphere. Journal of Power Sources. 2011;196(18):7627-763. DOI: 10.1016/j.jpowsour.2011.05.007

24. Liu L, Wu S, Dong Y, Lü S. Effects of alloyed Mn on oxidation behaviour of a Co-Ni-Cr-Fe alloy between 1050 and 1250 ${ }^{\circ}$ C. Corrosion Science. 2016;104:236-247. DOI: 10.1016/j. corsci.2015.12.016

25. Nguyen TD, Zhang J, Young DJ. Effects of cerium and manganese on corrosion of $\mathrm{Fe}-\mathrm{Cr}$ and $\mathrm{Fe}-\mathrm{Cr}-\mathrm{Ni}$ alloys in $\mathrm{Ar}-20 \mathrm{CO}_{2}$ gas at $818^{\circ}$ C. Corrosion Science. 2013;76:231-242. DOI: 10.1016/j. corsci.2013.06.046

26. Pieraggi B, Rapp R. A novel explanation of the "reactive element effect" in alloy oxidation. Journal de Physique IV Colloque. 1993;03(C9):C9-275-C9-280. DOI: 10.1051/jp4:1993926

27. Stefan E, Irvine JTS. Synthesis and characterization of chromium spinels as potential electrode support materials for intermediate temperature solid oxide fuel cells. Journal of Materials Science. 2011;46(22):7191-7197. DOI: 10.1007/s10853-010-4489-1

28. Golikov YV, Balakirev VF. Phase equilibrium diagram of the system Mn-Cr-O. Journal of Solid State Chemistry. 1987;71(2):562-565. DOI: 10.1016/0022-4596(87)90267-2

29. Wood GC. High-temperature oxidation of alloys. Oxidation of Metals. 1970;2(1):11-57. DOI: 10.1007/BF00603581

30. Stefan E, Connor PA, Azad AK, Irvine JTS. Structure and properties of $\mathrm{MgM}_{\mathrm{x}} \mathrm{Cr}_{2-\mathrm{x}} \mathrm{O}_{4}(\mathrm{M}=\mathrm{Li}, \mathrm{Mg}, \mathrm{Ti}, \mathrm{Fe}, \mathrm{Cu}, \mathrm{Ga})$ spinels for electrode supports in solid oxide fuel cells. Journal of Materials Chemistry A. 2014;2:18106-18114. DOI: 10.1039/ C4TA03633F

31. Nagai H. Improving Effect of Rare Earth Elements on the High Temperature Oxidation Resistance of Sintered Heat Resisting Alloys. Journal of the Japan Society of Powder and Powder Metallurgy. 1987;34(9):431-437. DOI: 10.2497/jjspm.34.431

32. Sarrazin P, Galerie A, Caillett M. Contribution to the understanding of the parabolic oxidation mechanism of dilute alloys. Part I: oxides with metal excess or oxygen deficit. Oxidation of Metals. 1996;46(1-2):1-17. DOI: 10.1007/BF01046881 